\title{
Nurse's activity in the promotion of breastfeeding in the family health strategy-an integrating literature review
}

\begin{abstract}
Introduction: Exclusive breastfeeding in the first six months of a baby's life brings benefits to both the newborn and the mother. Many mothers are aware of this benefit, but weaning rates before six months have a significant increase for several factors.

Objective: To describe, through an integrative review in the literature, the promotion of breastfeeding by nurses in the Family Health Strategy.

Method: The study was carried out by an integrative review of the literature, using the databases BDENF, LILACS, MEDLINE and Scielo, where three descriptors were defined: Breastfeeding, Nursing and Family Health, associating the term Boolean and. The historical cut was from 2014 to 2018.

Result: 516 articles were found and selected, according to the inclusion criteria, 16 of them.

Conclusion: The study concluded that the main actions of the nurse in the promotion of breastfeeding were cited as: to stimulate the participation of the family in the offered actions of support, incentive and promotion of breastfeeding; eliminate myths and beliefs about breastfeeding; guiding the correct handgrip of the newborn and the risks of using bottles and nipples; to guide the clinical management of breastfeeding; to assist in the difficulties of breastfeeding and, finally, to ensure prenatal and puerperal care.
\end{abstract}

Keywords: breastfeeding, nursing, family health, puerperal care, newborn
Volume 6 Issue 2 - 2019

\author{
Bruno Vilas Boas Dias,' Amanda Príncipe \\ Pagano, ${ }^{2}$ Bruna Guedes Miguel Gomes, ${ }^{2}$ \\ Débora Aline de Souza, ${ }^{2}$ Maryana Cristina \\ de Souza Marcondes, ${ }^{2}$ Michelle Gualassi \\ Zacari, ${ }^{2}$ Pamela Ane de Lima Viana, ${ }^{2}$ Rebecca \\ Ferronato de Azevedo, ${ }^{2}$ Thales Henrique dos \\ Santos, ${ }^{2}$ Rafael Antonio da Silva ${ }^{3}$ \\ 'Professor Master of the Undergraduate Course in Nursing, \\ Padre Anchieta University Center, Brazil \\ ${ }^{2}$ Graduating in Nursing, Padre Anchieta University Center, Brazil \\ ${ }^{3}$ Specialist Course in Nursing, Padre Anchieta University Center, \\ Brazil
}

Correspondence: Bruno Vilas Boas Dias, Professor master of the Undergraduate Course in Nursing, Padre Anchieta University Center and Campo Limpo Paulista University Center, Brazil,Email bruno.dias@anchieta.br

Received: March 21, 2019 | Published: April 16, 2019

\section{Introduction}

Breastfeeding occurs when the child receives breast milk, and can be direct from the breast or milked. According to the World Health Organization (WHO), it is recommended that it be exclusive until the six months of the baby's life, and from the beginning of the six months the complementary feeding begins, in view of the continued breastfeeding until the two years. This is considered a natural practice that brings several benefits to the child, as well as to the mother. ${ }^{1}$

Breastmilk is the most appropriate food for beginning the baby's nutrition because it contains all the nutrients in quantities that are compatible with the needs of the newborn, easy to digest and provide adequate growth. In addition, it provides antibodies that are able to prevent various types of infections that are recurrent in childhood, such as respiratory infections and diarrhea. In addition to being a natural linkage, protection and nutrition strategy, breastfeeding is necessary, especially in underdeveloped regions, due to the risk of diseases related to malnutrition, lack of sanitation and infections, as well as differential growth and development. compared with that of infants fed with artificial milk. ${ }^{2}$

As for the health of the mother, breastfeeding favors the return to pre-gestational weight, as well as the lower postpartum uterine bleeding. In addition, it has proven to be a protective factor against the appearance of breast and ovarian cancer in the same way, and may be a natural method to avoid a new pregnancy in the first six months. ${ }^{3}$
The duration of breastfeeding is related to biological, cultural, economic, social and health care factors. Thus, professionals can influence the onset and duration, stimulating this practice from the prenatal period and motivating the pregnant woman's ability to breastfeed. ${ }^{4}$

Even with the recommendation and importance of breastfeeding, the innumerable benefits of this practice and the proven protection of several diseases, nevertheless, advances are needed in Brazil. The prevalence of exclusive breastfeeding is $41 \%$, while the median duration is 11.2 months. According to WHO parameters, these data are categorized respectively as "reasonable" (ranging from 12 to $49 \%$ ) and "very bad" (range 0 to 17 months), evidencing the need for promotion practices. ${ }^{5}$

Since it is still a personal and public health problem, many women find it difficult to breastfeed, which, if not previously identified, may be possible causes for early weaning. ${ }^{6}$

It is estimated that the practice of breastfeeding can prevent about $13 \%$ of mortality in children under five years of age worldwide, thus generating a great benefit for the family and the health system, since many baby bottle expenditures can be avoided, artificial nipples, moreover, with medicines and consultations as a consequence of diseases that are common in non-breastfed children. Thus, the incentive to breastfeeding can be seen as an efficient and economical strategy for health promotion. ${ }^{7}$ 
It is also evident the importance of training health professionals in order to be able to identify and understand the real difficulties faced by mothers in order to promote good strategies to encourage breastfeeding. The professional needs to give a humanized, caring attention that respects the sociocultural context of each Family. ${ }^{7}$

The Family Health Strategy (FHS), implemented by the Ministry of Health as a resource to redirect the context of Primary Care in the country, covers conditions for promotion, protection and recovery of health, articulating all levels of care. This strategy is composed of a multidisciplinary team formed by at least a physician (generalist or specialist in Family Health), nurse (generalist or specialist in Family Health), auxiliary or nursing technician and community health agents, composing themselves also by other professionals in the team. ${ }^{5}$

Considering the aspect of health promotion, the incentive to breastfeeding can be seen as one of the actions contemplated by the FHS, the nurse participates actively in the promotion of this practice, especially during the period in which the pregnant women and puerperas present doubts, fears and insecurities due to expectations about breastfeeding. Therefore, it is important to explore the practices performed by nursing professionals to promote breastfeeding and the efficiency of these practices.

\section{Objective}

To describe, through an integrative review in the literature, the promotion of breastfeeding by nurses in the Family Health Strategy.

\section{Method}

This is a bibliographical survey, carried out through the scientific databases: Nursing Database (BDENF), Latin American and Caribbean Literature in Health Sciences (LILACS), Medical Literature Analysis and Retrieval System Online (MEDLINE) and virtual health library Scientific Electronic Libary OnLine (Scielo). As descriptors, the following keywords were used: Breastfeeding, Family Health and Nursing, associated with the Boolean operator "AND". The research was carried out in the first and second semester of 2018, obeying the inclusion criteria: articles published in Portuguese between 2014 and 2018; available in the databases consulted and in full text. The exclusion criteria adopted were: bibliographic review articles, editorials, abstracts, dissertations and theses.

It can be seen from Table 1 the number of articles that were obtained from the cross-referencing of the descriptors in each database. In Table 1 and Table 2, there is the list of articles according to the database, year, author, theme and conclusions.

\section{Result}

Table 1 shows the descriptors used, databases, number of articles found and articles selected, according to an integrative review of the literature. And Table 1 presents the articles in relation to the base, year, author, theme and conclusion.

Table I Relationship of the association of descriptors used, databases, number of articles found and articles selected

\begin{tabular}{llll}
\hline Descriptors & Base & Articles found & Selected articles \\
\hline Breastfeeding and Nursing & Lilacs & 64 & 2 \\
Breastfeeding and Nursing & Medline & 74 & 0 \\
Breastfeeding and Nursing & Bdenf & 49 & 1 \\
Breastfeeding and Nursing & Scielo & 32 & 2 \\
Breastfeeding and Family Health & Lilacs & 56 & 5 \\
Breastfeeding and Family Health & Medline & 55 & 0 \\
Breastfeeding and Family Health & Bdenf & 28 & 2 \\
Breastfeeding and Family Health & Scielo & 42 & 4 \\
Family Health and Nursing & Lilacs & 25 & 0 \\
Family Health and Nursing & Medline & 0 & 0 \\
Family Health and Nursing & Bdenf & 10 & 0 \\
Family Health and Nursing & Scielo & 81 & 516 \\
\hline Total & & & 0 \\
\hline
\end{tabular}


Table 2 List of articles according to the database, year, author, theme and conclusions

\begin{tabular}{|c|c|c|c|}
\hline Base & Year/Author & Theme & Conclusion \\
\hline Lilacs & Battaus et al. ${ }^{14}$ & $\begin{array}{l}\text { The promotion of Breastfeeding } \\
\text { in the Family Health Strategy - } \\
\text { Systematic Review. }\end{array}$ & $\begin{array}{l}\text { Elimination of myths and beliefs, guidance on handholding, correct } \\
\text { positioning, and prenatal and puerperal care. }\end{array}$ \\
\hline Lilacs & Costa et al..$^{13}$ & $\begin{array}{l}\text { Nurses' performance in } \\
\text { the clinical management of } \\
\text { breastfeeding: strategies for } \\
\text { breastfeeding. }\end{array}$ & $\begin{array}{l}\text { Guidance on the correct handle of the newborn and the risks of } \\
\text { the use of bottles and bottles, besides the clinical management of } \\
\text { breastfeeding. }\end{array}$ \\
\hline Bdenf & Santos et al. ${ }^{8}$ & $\begin{array}{l}\text { Nurses' performance in Basic } \\
\text { Health Units of the Breastfeeding } \\
\text { Friend. }\end{array}$ & $\begin{array}{l}\text { The need to train professionals in relation to breastfeeding. Promotion, } \\
\text { support and clarification of doubts that are scarce in the FHS. }\end{array}$ \\
\hline Lilacs & Oliveira et al. ${ }^{17}$ & $\begin{array}{l}\text { Popular practices and beliefs } \\
\text { associated with early weaning. }\end{array}$ & $\begin{array}{l}\text { The relevance of exclusive breastfeeding, nurses and health } \\
\text { professionals during the prenatal and puerperium to promote a } \\
\text { practice without myths and beliefs. }\end{array}$ \\
\hline Bdenf & Prates et al. ${ }^{12}$ & $\begin{array}{l}\text { Breastfeeding: The family } \\
\text { influence and the roles of health } \\
\text { professionals. }\end{array}$ & $\begin{array}{l}\text { The care of health professionals, and the family incentive, which is of } \\
\text { great importance for breastfeeding to continue effectively. }\end{array}$ \\
\hline Lilacs & Wernet et al 2014 & $\begin{array}{l}\text { Perception of the Family Health } \\
\text { team about the support to } \\
\text { Breastfeeding. }\end{array}$ & $\begin{array}{l}\text { Perception of competence of the professional team to support } \\
\text { mothers, pregnant women in relation to breastfeeding. }\end{array}$ \\
\hline Bdenf & Passos et al. ${ }^{10}$ & $\begin{array}{l}\text { Health professionals in } \\
\text { promoting breastfeeding: } \\
\text { integrative review. }\end{array}$ & $\begin{array}{l}\text { Involvement among the health professional, emphasizing the nurse with } \\
\text { the pregnant women to promote health practices and interventions } \\
\text { related to breastfeeding. }\end{array}$ \\
\hline Lilacs & Azevedo et al. ${ }^{15}$ & $\begin{array}{l}\text { The clinical management of } \\
\text { breastfeeding: nurses' knowledge. }\end{array}$ & $\begin{array}{l}\text { Guidance on the correct position and handhold of the newborn, } \\
\text { preventing intercurrences and favoring the mother-baby bond. }\end{array}$ \\
\hline Bdenf & Sousa et al.$^{6}$ & $\begin{array}{l}\text { Breastfeeding and the } \\
\text { determinants of early weaning. }\end{array}$ & $\begin{array}{l}\text { Weaning is related to factors of age, low income, return of activities, } \\
\text { work routine and lack of promotion of nursing activities. }\end{array}$ \\
\hline Lilacs & Barbieri et al. $^{7}$ & $\begin{array}{l}\text { Breastfeeding: guidelines received } \\
\text { during prenatal care, delivery and } \\
\text { puerperium. }\end{array}$ & $\begin{array}{l}\text { An increasing index of the conditions of the early weaning was } \\
\text { evidenced. }\end{array}$ \\
\hline Lilacs & Monteschio et al. ${ }^{14}$ & $\begin{array}{l}\text { The nurses facing early weaning } \\
\text { at the nursing visit to the child. }\end{array}$ & $\begin{array}{l}\text { Nurses' orientations regarding mammillary traumas, the use of bottles } \\
\text { and bottles and correct technique of storage of milked milk. }\end{array}$ \\
\hline Bdenf & Santos et al. ${ }^{8}$ & $\begin{array}{l}\text { Experiences of puerperal } \\
\text { mothers nursing in the practice } \\
\text { of Breastfeeding. }\end{array}$ & $\begin{array}{l}\text { Support to the woman, intervening in educational actions for the } \\
\text { correct knowledge of the practice of breastfeeding. }\end{array}$ \\
\hline Bdenf & Vargas et al. ${ }^{9}$ & $\begin{array}{l}\text { Performance of the health } \\
\text { professionals of the Family } \\
\text { Health Strategy: promotion of } \\
\text { the practice of breastfeeding. }\end{array}$ & $\begin{array}{l}\text { Need for professional engagement, providing health education, and } \\
\text { enabling the collective construction of knowledge. }\end{array}$ \\
\hline Bdenf & Teixeira et al. ${ }^{16}$ & $\begin{array}{l}\text { Nursing care for families who } \\
\text { experience breastfeeding. }\end{array}$ & Difficulties and facilities found by mothers when breastfeeding. \\
\hline Bdenf & Teles et al.2017 & $\begin{array}{l}\text { Knowledge and breastfeeding } \\
\text { practices of users of the Family } \\
\text { Health Strategy. }\end{array}$ & $\begin{array}{l}\text { Mothers' knowledge about the guidelines, which are often } \\
\text { ineffective provoking early weaning or food supplementation before } \\
\text { recommended. }\end{array}$ \\
\hline Bdenf & Batista et al. ${ }^{17}$ & $\begin{array}{l}\text { Health professionals' guidelines } \\
\text { on breastfeeding: the perspective } \\
\text { of puerperal women. }\end{array}$ & Importance of understanding of health education practices. \\
\hline
\end{tabular}




\section{Discussion}

After analyzing the articles, it can be observed that the main actions of nurses in promoting breastfeeding were cited as: encouraging the participation of the family in the actions offered to support, encourage and promote breastfeeding; eliminate myths and beliefs about breastfeeding; guiding the correct handgrip of the newborn and the risks of using bottles and nipples; to guide the clinical management of breastfeeding; assisting in the difficulties and, finally, ensuring prenatal and puerperal care.

The Basic Health Units play an important role in the support offered in relation to breastfeeding, offering theoretical knowledge and training of professionals, especially nurses, in order to provide continuous follow-up of puerperae who have difficulty in breastfeeding. Understanding, then, that only prenatal care is not sufficient to obtain knowledge about breastfeeding, having to continue this care during the puerperium. ${ }^{8}$

Nurses play an essential role in the promotion of breastfeeding, stimulating actions and extending until the moment of birth, followed by the assistance and encouragement of the FHS. One of the ten steps to successful breastfeeding, according to the Baby Friendly Hospital Initiative is to inform the pregnant woman about the preparation for breastfeeding, and should even be started during pregnancy, which shows a positive impact on prevalence and duration. ${ }^{9}$

Thus, health promotion affects the determinants and social determinants, generating a good quality of life, being characterized by actions of education, in which the nurse must support the woman, intervening of educational actions for the correct knowledge of the practice of breastfeeding. ${ }^{10}$

Family follow-up by nurses working outside maternity hospitals strengthens the continuity of exclusive breastfeeding, and the involvement of the health team along with the mother-child relationship and family is important, guiding the position of the mother, the baby, and the attachment correct of the areolar nipple region, breaking myths and taboos such as the "weak milk" that shows itself as responsible for early weaning and also for the early introduction of other foods, noting that there are negative consequences in this act. ${ }^{11}$

At the moment they are oriented by offering adequate and continuous support, mothers are aware of the importance of correct feeding and have all the support during the process of possible maternal suffering due to fissures and breast engorgement, thus being able to prolong the permanence of the breastfeeding. It is understood that it is necessary to establish attributions, full and humanized care of all health professionals, as well as the constant presence of family members, showing support and encouragement. ${ }^{12}$

Likewise, the nurse must offer emotional support, helping to overcome the obstacles in the breastfeeding process, dealing with the feelings manifested, being necessary the attention, empathy and decision making, in order to promote the autonomy of the woman. Acting in this way, the health professional is more likely to ensure the success of breastfeeding. Through the process of clinical management, with educational focus on the advantages and importance of breastfeeding on demand, and among other situations that generate doubts for the woman, in which it is essential to be carried out in the same way in home visits and consultations of puericulture. ${ }^{13}$

Many mothers report breastfeeding-related insecurities, highlighting myths such as "my milk is low, weak and insufficient," "my milk has dried up," "small breast does not produce enough milk," "breastfeeding falls," "milk maternal does not kill the baby's thirst "and" the baby did not want to pick up the breast. "These thoughts lead to the early introduction of baby bottles, pacifiers, teas, water and juices. The primary care nurse contributes with planning actions that provoke the necessary attitudes towards a good performance in breastfeeding. There are still shortcomings in this commitment of the professional, where information, knowledge, and guidelines are lacking. From the point of view of care, this lack is worrisome, insufficient and fragile, bringing attitudes harmful to the process of breastfeeding. ${ }^{13}$

It is also important to highlight the importance of maintaining exclusive breastfeeding after the mother's return to work, it is recommended that she breastfeed more frequently at home, avoiding the use of bottles, using the cup method, being sterilized and with safe edges , performing the milking during the working hours, in order to avoid the confusion of nozzles that occur due to the use of bottle, still to prevent milk stasis and engorgement and nipple traumas. The infant being fed by bottles is more likely to have some disease, malnutrition or overweight, and develop the facial muscles and impaired dentition. It becomes evident to the nurse's need to direct about the correct technique and to promote, mainly, the self-confidence of the nurse. ${ }^{14}$

For the correct handgrip, it is necessary that the mother is positioned in front of the baby, belly with belly, in which the lower lip should reach the nipple and the maximum possible of the areola, thus contributing to efficient breastfeeding and preventing breast intercurrences, as well as the quiet and comfortable environment that allows a more facilitative practice, preventing external interruptions and favoring the mother-baby bond..$^{15}$

In the treatment of nipple fissures, the recommended orientation is to use the milk itself, which forms a protective layer and prevents the dehydration of the epidermis, aiding in healing. ${ }^{14}$

Mothers who have flat or inverted nipples also report difficulties at the onset of breast-feeding, which does not prevent their breastfeeding, since at each sucking attempt the baby forms the nipple in the areola. However, breastfeeding provides a sense of well-being and pleasure in which you notice the importance of breast milk for your child's growth and development. ${ }^{16}$

Lastly, it is necessary for the FHS nurse to understand health education practices, so that they can provide effective and adequate assistance, in which women know and seek a differentiated form of care, being more and more humanized and welcoming, dealing with with the particularity of each one. ${ }^{17}$

\section{Conclusion}

This study concluded that the nurse's role in the Family Health Strategy, or in any Primary Care network is essential. The lack of knowledge of pregnant women and puerperas, the presence of doubts and beliefs reinforce the need for the presence of this professional in the actions to promote breastfeeding. It was clear that the main actions of nurses should be focused on encouraging the participation of the family, eliminating myths and beliefs, correct clinical management of breastfeeding, and informing the risks of the use of bottles and bottles. Thus, the search for knowledge related to breastfeeding should be prioritized and continuous, in order to increase the efficiency of 
guidelines and interventions. It should also be stressed that the focus should not only be on the domain of the subject, but on knowing how to relate this knowledge to the reality and individuality of each pregnant woman, giving the necessary support and support.

\section{Acknowledgments}

None.

\section{Conflicts of interest}

The authors declare there is no conflict of interest.

\section{References}

1. Ministry of Health. Breastfeeding. 2018.

2. Esteves TMB, Daumas RP, Oliveira MIC, et al. Factors associated with breastfeeding in the first hour of life: systematic review. Rev Saúde Pública. 2014;48(4):697-703.

3. Rocha LB, Araujo MS, Rocha NCO, et al. Aleitamento materno na primeira hora de vida: uma revisão da literatura. Rev Medicina e Saúde de Brasília. 2017;6(3):384-394.

4. Ministry of Health. Promoting breastfeeding. 2nd ed. 2007.

5. Venancio S. Indicators of breastfeeding, exclusive breastfeeding and complementary feeding.

6. Amaral LJ, Sales SS, Carvalho DPSRP, et al. Factors influencing the interruption of exclusive breastfeeding in nursing mothers. Rev Gaúcha de Enfermagem. 2015;36:127-134.

7. Ministry of Health. Child health: breastfeeding and complementary feeding. 2nd ed. 2015. $186 \mathrm{p}$.
8. Santos FCS, Cyrino ACT, Santos FS, et al. Nurses' performance in basic health units that are breastfeeding friendly. Rev Rene. 2014;15(1):70-77.

9. Vargas GS, Alves VH, Rodrigues DP, et al. Health professionals' performance in the family health strategy: promotion of the practice of breastfeeding. Revista Baiana de Enfermagem. 2016;30(2):1-9.

10. Passos LP, Pinho L. Health professionals in promoting breastfeeding: integrative review. Rev Enferm. 2016;10(3):1507-1516.

11. Battaus MRB, Liberali RA. The promotion of breastfeeding in the family health strategy-a systematic review. Rev APS. 2014;17(1):93-100.

12. Prates LA, Schmalfuss JM, Lipinski JM. Breastfeeding: family influence and the role of health professionals. Rev Enferm UFSM. 2014;4(2):359367.

13. Costa EFG, Alves VH, Souza RMP, et al. Nurses' performance in the clinical management of breastfeeding: strategies for breastfeeding. Rev Fund Care Online. 2018;10(1):217-223.

14. Monteschio CAC, Gaíva MAM, Moreira MDS. The nurses facing early weaning at the nursing visit to the child. RevBrasEnferm. 2015;68(5):869875 .

15. Azevedo ARR, Alves VH, Souza RMP, et al. The clinical management of breastfeeding: nurses' knowledge. Escola Ana Nery Rev Enfermagem. 2015;19(3):439-445.

16. Teixeira MA, Luz RT, Cruz MG, et al. Nursing care for families who experience breastfeeding. Rev Enferm UFPE online. 2017;11(8):31903197.

17. Batista MR, Veleda AA, Coelho DF, et al. Guidelines of health professionals on breastfeeding: the look of puerperae. J Nurs Health. 2017;7(1):25-37. 